УДК $37.04+373.3+376-056.36$

DOI: 10.15330 /esu. 16. 214-226

\section{Світлана Чупахіна,}

кандидат педагогічних наук, доцент,

ДВНЗ "Прикарпатський національний університет імені Василя Стефаника" (м. Івано-Франківськ, Україна)

SvitlanaChupakhina, Candidate of pedagogical sciences $(\mathrm{PhD})$, Associate Professor, Vasyl Stefanyk Precarpathian National university (Ivano-Frankivsk, Ukraine) cvitlana2706@gmail.com

\title{
ТЕОРЕТИЧНІ ЗАСАДИ ІТ-ПІДТРИМКИ ІНКЛЮЗИВНОГО НАВЧАННЯ МОЛОДШИХ ШКОЛЯРІВ 3 ОСОБЛИВИМИ ОСВІТНІМИ ПОТРЕБАМИ
}

\section{THEORETICAL FOUNDATIONS OF INFORMATIONAL TECHNOLOGIES SUPPORT IN INCLUSIVE EDUCATION OF PUPILS WITH SPECIAL EDUCATIONAL NEEDS}

В статті проаналізовано зарубіжний досвід иодо використания інформачійних технологій в інклюзивному навчанні молодиих иколярів з особливими освітніми потребами. Доведено, цо важливим завдания сучасної иколи стас повнота використания можливостей інформачійних технологій, їх потенціалу в навчанні дітей з особливими освітніми потребами. Актуальності набуває саме вивчення та розумне використання зарубіжного досвіду, співзвучного загальносвітовим тендениіям оновлених підходів до освіти в Украӥні.

Доведено, ио в інклюзивній освіті означені технологій спроможні допомогти дітям $з$ особливими освітніми потребами задовольнити право на освіту, розкрити свій потенціал й реалізувати себе як особистість у сочіальному житті. Використання інформаџійно-комунікаційних технологій у навчанні иколярів означеної категорії сприяє розвитку і корекиії психофізичних прочесів: мислення, пам'яті, моторики, оріснтації в просторі тощо.

Описано основні переваги та напрямки інформачійно-комунікаційної підтримки інклюзивного навчання молодиих иколярів з особливими освітніми потребами.

Доведено, ио навчально-програмне забезпечения, віртуальні освітні середовища, які використовуються в навчальному прочесі, повинні проектуватися та розроблятися $з$ урахуваниям інклюзивних стратегій, задля доступу та використания будь-яким індивідом незалежно від індивідуальних особливостей та поруиень. Отож закладам освіти важливо забезпечити універсальний дизайн технологій, які вони використовують, та їх відповідність вимогам Конвениії ООН.

Обгрунтовано, щуо задля забезпечення ефективного освітнього впливу на дітей з особливими освітніми потребами важливим стас розробка особистісно оріснтованих навчальних програм, проектування індивідуальних освітніх траєкторій. Завдяки використанню хмарних технологій (на прикладі Північної Ірландії, ШІотландії, Канади, Малайзії, США), можемо стверджувати, що діти з особливими освітніми потребами отримують доступ до різноманітних дидактичних матеріалів у прийнятній, доступній $i$ иікавій форматі.

Узагальнено, ио розвиток та впровадження хмарних технологій у прочес навчання дітей з особливими освітніми потребами уможливлюс подолания пизки дидактичних бар'єрів, отримання доступу до різноманітних матеріалів у прийнятному форматі, иео знаходить відображения в зарубіжній практичі.

Ключові слова: інформачійно-комунікачійні технології, віртуальні освітні середовища, інклюзивне навчання, інформачійно-комунікачійної підтримки інклюзивного навчання, молодиі школярі з особливими освітніми потребами, хмарні технології. 
The article deals with foreign experience of using information technologies in teaching pupils with special educational needs. It is proved that the crucial task of modern school is to take full advantage of information technologies as well as their potential in teaching children with special educational needs. The study and reasonable application of foreign experience which is consistent with the global tendencies of updated approaches to education in Ukraine, is becoming urgent.

It has been proven that in inclusive education the technologies are able to help children with special educational needs meet the right to education, discover their potential and realize themselves as a person in social life. The application of information and communication technologies in the education of mentioned pupils promotes the development and correction of psychophysical processes: thinking, memory, motor skills, orientation in space, etc.

The main advantages and directions of information and communication support in inclusive education of pupils with special educational needs are described.

It has been proven that educational software, virtual educational platforms used in teaching process must be designed and developed with regard to inclusive education strategies, for being accessed and used by any pupil, regardless of individual characteristics and disorders. Therefore it is important for educational establishments to ensure the universal design of the technologies they use and their compliance with the requirements of the UN Convention.

It is substantiated that in order to ensure effective educational impact on children with special educational needs, it is important to develop personally oriented curricula and design individual educational plans. Thanks to the application of cloud technologies (for example, Northern Ireland, Scotland, Canada, Malaysia, USA), we can state that children with special educational needs have access to a variety of didactic materials in an acceptable, accessible and interesting way.

It is summarized that the development and implementation of cloud technologies in the process of teaching children with special educational needs makes it possible to overcome a number of didactic problems, access to a variety of materials in an acceptable way which is reflected in foreign practice.

Key words: information and communication technologies, virtual educational platforms, inclusive learning, information and communication support of inclusive education, pupils with special educational needs, cloud technologies.

Постановка проблеми. В сучасних умовах нформаційно-комунікаційні технології (ІКТ) стали значущою рушійною силою глобалізації суспільства. Проблеми інформатизації освіти, використання інформаційних технологій (IT) $€$ надзвичайно важливим, зокрема саме для системи інклюзивного навчання. Особливого значення набуває творче впровадження в практику навчально-виховної роботи нових технологій та методик. Для загальноосвітньої школи - це, насамперед, поліпшення результативності навчальної та розвиткової роботи, що $є$ основою загальноосвітньої підготовки учнів. Використання можливостей IT дозволяє також успішно вирішувати важливі завдання навчання та виховання дітей 3 особливими освітніми потребами (ООП). Відтак проблема опанування IT учнями з ООП постає надзвичайно гострою, оскільки набуття інформатичних знань взаємопов'язано із засвоєння матеріалу та особливостями розвитку.

У галузі інклюзивної освіти означені технології спроможні допомогти дітям 3 ООП задовольнити право на освіту, розкрити свій потенціал й реалізувати себе як особистість у соціальному житті. Використання IКТ у навчанні школярів означеної категорії сприяє розвитку і корекції психофізичних процесів: мислення, пам'яті, моторики, орієнтації в просторі тощо. 
В Україні інклюзивна освіта знаходиться на етапі адаптації навчальних програм та планів, розвитку методів і форм навчання, використання інформаційнокомунікаційних ресурсів, які здатні забезпечити індивідуальні освітні потреби дітей з ООП. Результати центру громадського моніторингу і контролю засвідчують, що серед 17337 українських шкіл лише 1127 адаптовані до потреб інклюзивного навчання. Більш ніж 56 тисяч школярів з ООП взагалі не охоплено навчанням у загальноосвітніх закладах [2].

Як зазначено в документах ЮНЕСКО, сучасний рівень розвитку ІКТ значно розширює можливості педагогів та учнів, спрощуючи доступ до освітньої $\mathrm{i}$ професійної інформації, розширює функціонал засобів навчання та ефективність управління освітнім процесом, сприяє інтеграції національних інформаційних освітніх систем у світову мережу, доступу до міжнародних інформаційних ресурсів в галузі освіти, науки і культури [11].

Актуальність дослідження і публлікації. Різноманітін аспекти впровадження IT в інклюзивну освіту широко розробляються зарубіжними та вітчизняними вченими й практиками. Так, дослідники М. Тернер-Чучалта, С. Айткен виявили три потенційно дієвих важелі, які слід використовувати у спробах подолання цифрового розриву і розповсюдження IКТ як ефективного інструменту в інклюзивному навчанні. Важливою стає саме державна підтримка й фінансування, загальнодержавна програма навчання для дітей з ООП, підтримка та сприяння інклюзивній освіті на рівні шкіл й громади. Науковець С. Грін представила методичні рекомендації щодо розробки навчальних програм 3 інформаційно-комунікаційних технологій для школярів з особливими потребами у загальноосвітніх закладах освіти. Англійські дослідниці університету Нортгемптона Сулата Аджит Санкардаста Джаяшрі Раджанахаллі теоретично обгрунтували й експериментально підтвердили ефективність застосування електронних засобів масової інформації підчас освітньої діяльності школярів з розладом аутичного спектра. Педагоги Мінвук Ок, Мін Кьон Кім, Юн Янг Канг, Брайан Р. Брайант [5] переконані у дієвості мобільних пристроїв як засобів навчання для школярів з ООП.

Широке запровадження та використання IKT сприяє оновленню моделей навчання, розвитку освіти на засадах відкритості, безперервності, доступності, особистісного спрямування, соціальної справедливості та рівних можливостях для всіх категорій населення, водночас і осіб з ООП [3].

Зарубіжний досвід використання означених технологій в освіті знаходить відображення в дослідженнях вітчизняних науковців: О. Гриценчук, І. Капустян, Н. Кіяновської, О. Локшиної, І. Малицької, О. Овчарук, Н. Сороко та ін. Різноманітні аспекти використання IКТ в роботі з дітьми з ООП представлено в роботах таких учених, як: В Вєселов, Н. Вострокнутова, В. Демкіна, М. Захарчука, Л. Коваль, Т. Королевської,К. Косової,Н.Курбатової, Б. Мороз, Ю. Носенко, В. Овсянник, С. Чупахіної, О. Чупріної та ін.

Застосуванням технологій Веб в навчанні осіб з ООП присвячено дослідження В. Григорович [1].

Вченим Ю. Носенко виділено три основні шляхи використання IКТ в інклюзивній освіті з певною метою [3]:

- компенсації (використання ІКТ як технічної допомоги, підтримки, часткової компенсації чи заміщення відсутніх природних функцій, що дозволяс учням 3 ООП повноцінно залучатись до процесів спілкування й взаємодії); 
- комунікації (допоміжні прилади й програмне забезпечення, альтернативні форми зв'язку, що полегшують чи уможливлюють комунікацію у більш зручний спосіб, специфічний для кожного виду функціонального обмеження);

- дидактичного засобу (сприяють диференщіації, задоволенню індивідуальних потреб, особистісному розвитку дітей з ООП, розкриттю їхніх здібностей, повноцінній інклюзії, включенню в освітнє й суспільне середовище).

Мета статті: обгрунтуквати можливості інформаційно технологічної підтримки інклюзивного навчання молодших шкколярів з ООП та тенденції використання означених технологій в освіті учнів з ООП зарубежем задля успішного їх використання в умовах інклюзивного освітнього середовища України.

Виклад основного матеріалу. Варто зауважити, що засоби IКТ, зокрема асистивні (допоміжні) технології та допоміжне програмне забезпечення, доцільно добирати 3 урахуванням особливостей порушень в учнів. Педагогічно виважене й доцільне використання ІКТ дозволить учням 3 ООП повноцінно включитися в освітній процес, розвивати прийнятні для них індивідуальні освітні стратегії.

Широке використання IКТ та інтерактивних мультимедіа, спрощений доступ до глобальних мереж, зокрема, Інтернет, дозволяє стверджувати, що [10]:

- процес навчання поступово стає незалежним від фізичного розташування його суб'єктів;

- кількість і різноманітність ресурсів, доступних учням у позаурочний час суттєво зросла;

- локус контролю в ініціації навчального процесу відійшов учням: вони самі здатні ініціювати процес у будь-який зручний для них час, у будь-якому місці.

У науково-педагогічних дослідженнях серед основних типів IКТ, доцільних для використання як засобу підтримки інклюзивного навчання, виокремлюють [9]:

- стандартні технології - персональні комп'ютери (настільні ПК, переносні ПК (ноутбуки, нетбуки), планшетні ПК (планшети) тощо) 3 вбудованими функціями налаштування для осіб з ООП;

- доступні формати даних, або альтернативні формати - скажімо, доступний HTML;

- DAISY - стандарт цифрового формату для запису цифрових аудіо книг (digital talking books); брайлівські принтери, дисплеї тощо;

- асистивні (допоміжні) технології - слухові апарати, пристрої для читання 3 екрану, клавіатури зі спеціальними можливостями, системи альтернативної комунікації тощо.

Основні переваги ІКТ підтримки інклюзивного навчання подано на рис. 1. 


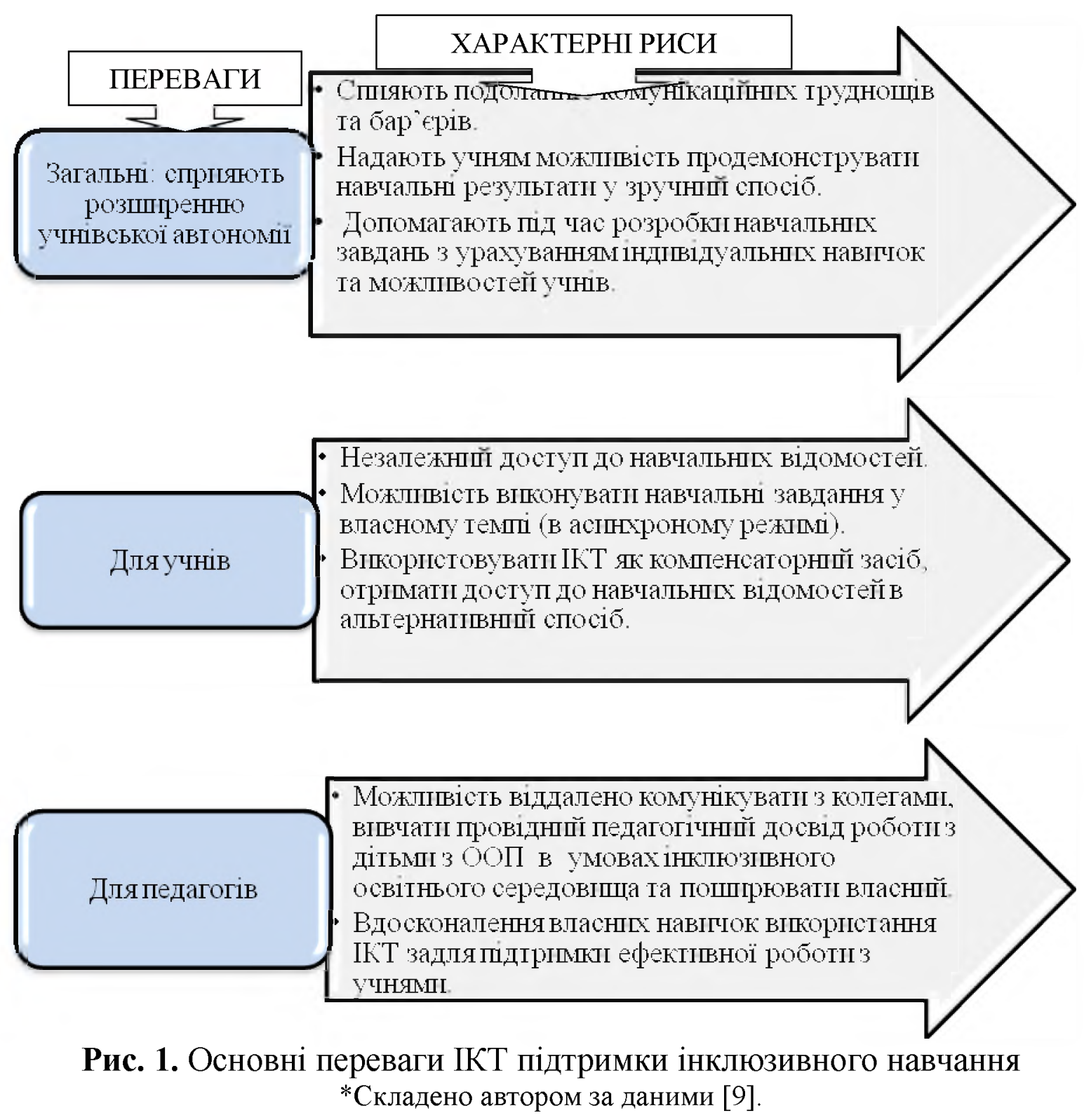

Основні напрямки, за якими доцільно проводити ІКТ підтримку інклюзивного навчання зображено на рис. 2. 
Визначення початкового рівня особистісного розвитку

Учня, тобто вІхХдного рівня, 3 якцм він розпочннає

навчання

Підтримка особистісного розвитку шшяхом формування нових навигок чп розвитку вже набутпх

Покращення доступу до освітніх ресурсів

Подолання географічної чп соціальної недоступності,

шпяхом комунікаційної та мережевої підтрпмки

Посплення мотивації до використанщя та обізнаності щодо переваг IКТ як засобу підтримк інклюзивного навчання

Рис. 2. Основні напрямки ІКТ підтримки інклюзивного навчання

*Складено автором за даними [9]. (рис.3).

Однак впровадження IКТ в інклюзивну освіту зумовлює появу низки проблем

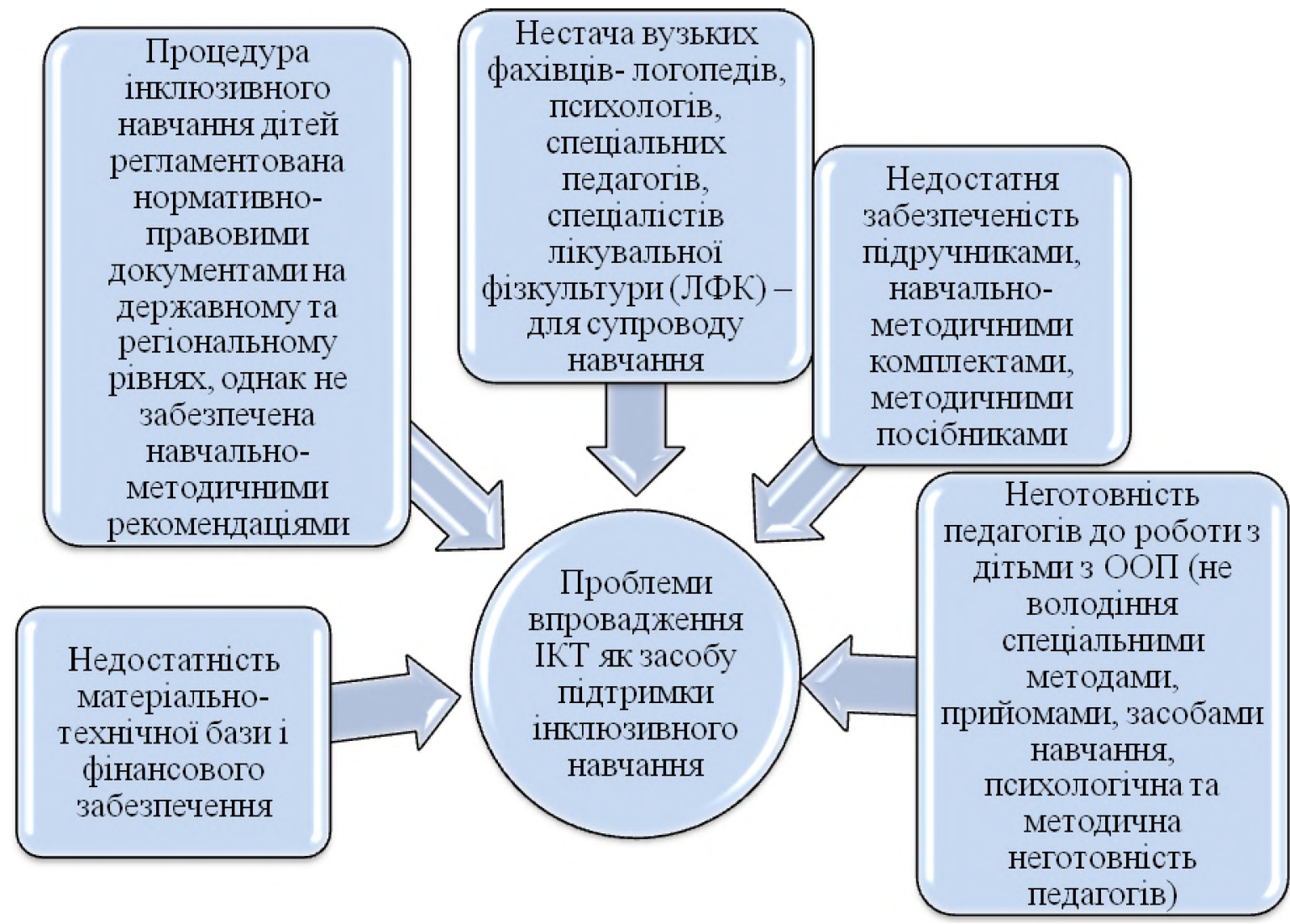

Рис. 3. Проблеми впровадження ІКТ як засобу підтримки інклюзивного навчання

*Складено автором за даними [3;9]. 
Задля уникнення означених проблем та успішної реалізації інклюзивного навчання з ІКТ підтримкою задля підвищення якості та доступності освіти осіб з ООП важливо забезпечити відповідні умови (рис.4).

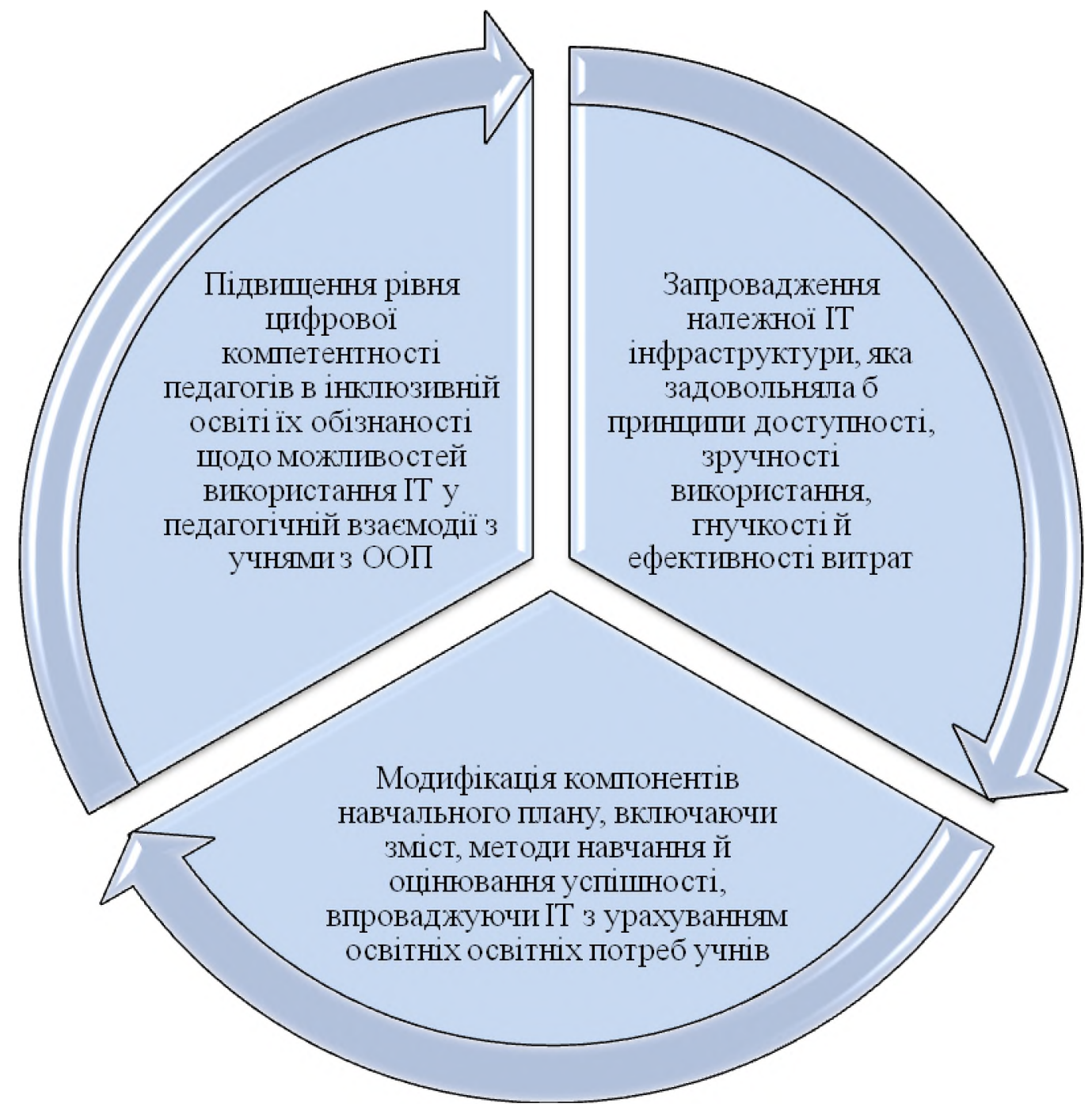

Рис. 4. Умови успішної реалізації інклюзивного навчання з ІКТ підтримкою задля підвищення якості та доступності освіти осіб з ООП *Складено автором

Розвиток та доступність веб- і хмаро орієнтованих технологій дозволяють створити підгрунтя для поширення актуальних навчальних відомостей у більш швидкий й гнучкий спосіб. Низка технологічних рішень, доступних $\mathrm{i}$ часто безкоштовних, сприяють розвитку середовищ ефективної навчальної взаємодії: синхронної та асинхронної комунікації і колаборації (електронна пошта, онлайн дошки, чати, форуми, веб-конференції тощо); мультимедійної інтеракції (симуляції, доповнена реальність, гейміфікація); інноваційних методик оцінювання (адаптивне тестування, самооцінювання, онлайн-тестування тощо) [6].

Також навчально-програмне забезпечення, віртуальні освітні середовища, які мають широке використання в навчальному процесі, повинні проектуватися та розроблятися з урахуванням інклюзивних стратегій, задля доступу та використання будь-яким індивідом незалежно від індивідуальних особливостей та порушень. 
Відтак закладам освіти важливо забезпечити універсальний дизайн технологій, які вони використовують, та їх відповідність вимогам Конвенції ООН.

Під інклюзивною освітою розуміємо етап становлення загальної освіти, в якому можливість отримання знань доступна всім, і дітям 3 ООП зокрема. В зарубіжних країнах означений підхід до освіти розвивається впродовж тривалого часу i $є$ законодавчо закріпленим. Сутність інклюзивної освіти становить система поглядів, яка не допускає будь-яку дискримінацію дітей, а також допомагає реалізувати в освітньому середовищі саме ті необхідні умови, які важливі дітям.

Американська освіта розглядає інклюзію як кардинальне перетворення школи під завдання й потреби спільного навчання звичайних дітей і дітей 3 проблемами в розвитку. У німецькомовних країнах термін "інклюзія" майже не вживається, здебільшого послуговуються термінами “інтеграція”, “спільне навчання”, “включення”. Країни, що орієнтуються на американську освітню модель, ширше використовують термін “інклюзія".

Розвинені зарубіжні країни демонструють самобутній досвід упровадження інформаційних технологій в освітню практику на всіх рівнях, водночас і в галузі інклюзивної освіти. Хоча підходи до реалізації освіти дітей з ООП в кожній країні мають свої особливості, усі вони розглядають ІКТ як основний інструменту реалізації інклюзивних стратегій [3].

Отож задля утворення дійсно відкритого освітнього середовища необхідні технології, які дозволили б віддалено оперувати всіма необхідними даними: дослідженнями, документацією, дидактичними й методичними напрацюваннями тощо, надаючи до них загальний доступ, можливість спільного користування та/чи редагування, обміну. Такі можливості надають технології на основі концепції хмарних обчислень [3].

Розвиток та впровадження хмарних технологій у процес навчання дітей з ООП уможливлює подолання низки дидактичних бар'єрів, отримання доступу до різноманітних матеріалів у прийнятному форматі, що знаходить відображення в зарубіжній практиці.

Великобританія (Північна Ірландія). У країні впровадження новітніх технологій в освіту здобуло широку прихильність й підтримку уряду. Яскравим прикладом цього є започаткування у 2012 р. програми "Освітня мережа Північної Ірландії" (Education Network Northern Ireland) за державним фінансуванням. У межах програми у школи країни запроваджено сучасне обладнання для підтримки широкосмугового доступу до мережі Інтернет, цілу низку електронних освітніх ресурсів, а також середовище “Освітня хмара" (Education Cloud environment), що містить учнівський портал “Моя школа" ('My-School'), адаптований до різних вікових категорій та рівнів розвитку дітей, і навчальну платформу. Тільки у перші п’ять років в хмару інвестовано $£ 170$ млн [3].

Ідея створення хмари полягає в розвитку динамічного, перспективного гнучкого сервісу, який забезпечив би надійний якісний доступ до широкого пулу освітніх ресурсів. Означений підхід сприяє підтримці взаємодії (колаборації) між навчальними закладами, залученню персональних мобільних гаджетів (смартфонів, планшетів тощо) у навчальний процес, розвитку актуальних навичок в учнів, незалежно від їх місця знаходження та функціональних особливостей.

Реалізація ідеї надасть вчителям та учням 3 ООП доступ до кращих навчальних ресурсів з усього світу. Доступ до “цифрового класу", уроків та ресурсів можна отримувати цілодобово 3 будь-якого пристрою, підключеного до мережі 
Інтернет, що дозволить вчителям, учням та батькам працювати в реальному партнерстві для підтримки навчання [15].

Великобританія (Шотландія). У країні на державному рівні запроваджено програму "Curriculum for Excellence", що забезпечує підтримку інклюзивного навчання дітей та підлітків від народження до 18 років. Розроблено і впроваджено гнучкі навчальні плани для різних вікових категорій: від 0 до 5 років; від 3 до 5 років; від 5 до 14 років і т.д. Означена програма реалізується на засадах дидактичних принципів: активності, проблемності навчання; підтримки холістичного підходу (для цілеспрямованого всебічного розвитку особистості); наступності у навчанні; навчання через гру [3].

Найбільш знаковою розробкою в контексті інклюзивного навчання вважаємо Glow (запроваджується з 2009 р.) - перший у світі Інтранет національного рівня, створений з освітньою метою, що консолідує різноманітні освітні ресурси для дітей, учнів та педагогів. Інтранет - свого роду цифрове середовище для підтримки навчання, доступне на всій території Шотландії. Розробка фінансується за рахунок державного бюджету [13].

Усім користувачам Glow, зокрема педагогам та учням, безкоштовно присвоюється індивідуальний обліковий запис (акаунт), що забезпечує доступ до будь-яких сервісів і ресурсів, які можна використовувати в освітньому контексті. Адміністрування здійснюється як на рівні навчального закладу і на рівні місцевого органу управління. Система Glow підтримує доступ до низки інструментів для безпечної надійної взаємодії: хмарного офісного пакету Microsoft Office 365, чату (Glow Chat), служби миттєвих повідомлень (Glow Messenger), електронної пошти (Glow Mail), сховища документів (Document Stores), а також [13]:

- Glow Meet - сервіс для проведення веб-конференцій на основі Adobe Connect;

- Glow Blogs - сервіс на основі WordPress blogs для створення блогів потужного і гнучкого інструменту для колаборативного навчання;

- Glow Forums - сервіс для ведення форумів, асинхронної навчальної взаємодії в середовищі, орієнтованого на користувача (userfriendly environment);

- Glow Wikis - онлайн простір на основі Wikispaces, що дозволяє створювати “вікі" для ефективної групової взаємодії;

- Glow Learn - інтегроване віртуальне навчальне середовище, що дозволяє створювати навчальні курси й обмінюватися ресурсами між освітянами Шотландії;

- Glow Groups - під-сайти, що можуть створюватись освітянами в кожному навчальному закладі з різною метою (скажімо, група окремого класу, школи, предметної групи, групи викладачів певних дисциплін тощо). На національному рівні створено групи до кожного навчального плану (curricular) для заохочення співпраці в усій країні.

y Glow створено професійний навчальний хаб для підтримки суб'єктів інклюзивної освіти, що дозволяє проводити дискусії, обмінюватися матеріалами i досвідом у цій сфері, демонструвати практичні здобутки тощо. Використання Glow сприяє забезпеченню гнучкості й доступності освітнього процесу, відкриває широкі можливості для навчальної комунікації та співпраці у безпечному хмаро орієнтованому середовищі з будь-якого місця, в будь-який час, 3 використанням будь-яких пристроїв, підключених до мережі Інтернет [3].

Канада. У Канаді започатковано стратегічний проект загальнодержавного значення “Цифрова Канада 150” (Digital Canada 150) та має привести до “процві- 
таючої цифрової Канади" ('thriving, digital Canada'). Головна мета проекту: ефективна цифрова політика, забезпечення громадян швидкісним надійним доступом до мережі Інтернет та новітніх IT у всіх сферах діяльності - економіці, соціальній сфері, бізнес-секторі, гуманітарній сфері, освіті тощо. Забезпечення безпечності, низької вартості та доступності цифрових сервісів для всіх категорій громадян є особливою прерогативою державної політики Канади [7].

Успішність проекту зумовила необхідність його продовження (оновлена назва - “Цифрова Канада 150, версія 2.0” (Digital Canada 150 2.0). У найближчих стратегічних планах Канади - розгортання хмарної мережі (Canada Cloud Network), однією 3 переваг якої стане можливість консолідувати всі дані, всю інформацію в межах країни, без використання серверів інших держав. Канадські дослідники наголошують на зростанні попиту на "інклюзивно" спроектовані сервіси, що доступні для всіх. Для більш ефективної реалізації означеного проекту доцільно створити єдиний спільний домен, що акумулював би інклюзивно орієнтовані ресурси різних розробників. Саме хмарні технології $\epsilon$ тим засобом, що дозволить консолідувати ресурси та зробить їх доступними, незалежно від місця розташування користувача, сприятиме реалізації персоніфікованого підходу. Окрім сприяння доступності, такий підхід дозволить створити загальну платформу для постійного оновлення ресурсів і їх покращення.

Малайзія. У Малайзії особи з ООП можуть у повній мірі реалізувати своє право на освіту в межах сектору формальної освіти відповідно до Малазійського Акту про осіб з особливими потребами 2008 року (Malaysian People With Disability Act). Реалізація прав дітей з ООП знаходиться в межах компетентностей трьох відомств: Міністерства охорони здоров'я (Ministry of Health), Міністерства у справах жінок, сім'ї та соціального розвитку (Ministry of Women, Family and Community Development) та Міністерства освіти (Ministry of Education). Сфера компетентності розподіляється залежно від виду функціональних обмежень. Скажімо, до юрисдикції Міністерства освіти належать питання, пов'язані з сидромом Дауна, легкими формами аутизму, синдромом дефіциту уваги і гіперактивності, вадами зору й слуху та ін. Міністерські програми спеціальної освіти спрямовано на забезпечення фізичного, емоційного, духовного й інтелектуального розвитку кожного учня. Головна мета - надати можливість кожному в повній мірі розкрити свій освітній, професійний і життєвий потенціал [3].

Інклюзивна освіта в Малайзії реалізується в межах програми інтеграції (Special Education Integration Programme), відповідно до якої учні з ООП групуються в окремому класі. У випадку, якщо учень досягає освітніх результатів на рівні середніх показників (навіть нижнього щабля середніх показників розвитку), його може бути переведено до звичайного класу і він продовжує своє навчання разом із однолітками 3 нормотиповим розвитком. Якщо ж його результати погіршаться, його знову переведуть до спеціального класу [4, с. 335].

Малайзійські дослідники вбачають перспективу розвитку IКТ підтримки інклюзивного навчання в запровадженні доповненої реальності, зокрема з урахуванням використання хмарних технологій. Доповнена реальність (Augmented Reality) - це різновид віртуальної реальності, на відміну від якої вона не занурює учня у віртуальне синтетичне середовище, а “поєднує” віртуальні об'єкти 3 реальним світом. Іншими словами, доповнена реальність не заміщує дійсність, а доповнює їі. В загальному розуміння означена технологія реалізується через нашарування на об'єкти реального світу віртуальних зображень - голограм. Переваги очевидні: 
потужна активізація уваги й мотивації учнів; значне покращення розуміння навчального матеріалу та його запам'ятовування; вирішення проблем нестачі обладнання й ресурсів для проведення навчальних експериментів, можливість їх реалізації у безпечному середовищі; скасування часових і просторових меж - можна візуалізувати будь-які об'єкти минулого й сучасності. Здебільшого додатки доповненої реальності $\epsilon$ великими за обсягами, що часто унеможливлює їх використання на персональних комп'ютерних і мобільних пристроях, які мають обмежені ресурси пам'яті. Означену проблему можна вирішити шляхом впровадження хмарних технологій, що надають можливості віддаленого опосередкованого зберігання й опрацювання, надійного збереження і захисту даних, ефективного обміну контентом між освітянами та розробниками [3].

США. У США право дітей на інклюзивну освіту закріплено на законодавчому рівні. Вирішальним документом став закон "Про освіту осіб з ОПП" (1990), у якому вперше було замінено поняття “дитина 3 інвалідністю" на “дитина 3 особливими освітніми потребами" [3].

У США закон зобов'язує державні школи надавати спеціальні освітні послуги дітям з ООП. Однак, деякі школи в окремих регіонах не мають достатньо розвиненої інфраструктури й оснащення для того, щоб у повній мірі задовольнити потреби цієї категорії учнів, особливо в ситуації стійкого зростання їх кількості [14].

Результати звіту Мережі моніторингу аутизму та відхилень розвитку (Тhe Autism and Developmental Disabilities Monitoring (ADDM) Network) засвідчують, що в однієї з 88 дітей у віці від 3-х до 17 років діагностовано аутизм. Причини такої значної кількості, 3 одного боку, $є$ покращення засобів медичної діагностики, а 3 іншого - в збільшенні кількості випадків народжуваності дітей з порушеннями [14].

Поширеною практикою стало залучення приватних осередків до освітнього сектору. "Освітні послуги Америки" (Educational Services of America (ESA) - це приватна компанія, що $є$ лідером на національному ринку США 3 упровадження альтернативних навчальних програм для дітей з ООП. Наразі вона співпрацює 3 понад 240 державними школами в 22 штатах і задовольняє особливі освітні потреби більше 12000 учнів кожного року [8].

Уже впродовж багатьох років ESA використовує рішення приватної хмари Citrix для перетворення навчання в інтегровану частину життя тих, хто в силу різних життєвих та медичних обставин не може скористатися освітніми послугами в традиційний спосіб. Розгортання хмари по всій мережі закладів ESA вимагало значних витрат (понад 1 млн дол.). Витрати на обслуговування хмарних сервісів частково лягають на державні школи, які одержують асигнування зі спеціального держфонду для навчання дітей 3 ООП. Для учнів користування сервісами $\epsilon$ безкоштовним [8].

Першим сервісом, 3 якого ESA розпочала використання хмари, став Citrix XenDesktop - комплексне рішення для віртуалізації, що на одній уніфікованій платформі забезпечує надійний віддалений доступ до низки застосування з будьяких пристроїв. Citrix XenDesktop дозволяє створювати віртуальні робочі/навчальні місця 3 повноцінною підтримкою 3D графіки, завдяки яким учні можуть віддалено використовувати різні візуальні застосунки, водночас і OC Windows, віртуальні робочі столи, Microsoft Office тощо. 3 хмарними технологіями Citrix NetScaler, Repeater та Branch Repeater учні залучаються до роботи 3 графічно насиченим мультимедійним контентом, що враховує їх індивідуальні особливі потреби. Citrix дозволяє ESA розгортати їі додатки поряд з іншими веб-орієнтованими додатками в 
одному середовищі, в результаті чого досягається максимальна гнучкість у виборі програм, доступних учням. Означені технології Citrix дозволяють учням з ООП ефективно включитися в навчальний процес у зручний для них спосіб, мати доступ до якісних освітніх ресурсів, вчасно й успішно проходити стандартизоване тестування, взаємодіяти з учителями й однолітками [8].

Висновки. Отож сучасна ідеологія інформаційного суспільства (суспільства знань) потребує включення кожного суб'єкта в процеси навчання, пізнання, творчого розвитку. Все це вимагає пошуку альтернативних шляхів отримання освіти тими, хто в силу соціальних, медичних чи інших причин не може досягти цього традиційними методами. Задля забезпечення ефективного освітнього впливу на дітей з ООП важливим стає розробка особистісно орієнтованих навчальних програм, проектування індивідуальних освітніх траєкторій. Враховуючи зарубіжний досвід, властивості інформаційних технологій допомагають дітям 3 ООП брати активну участь у навчальному процесі попри порушення. Завдяки використанню хмарних технологій (на прикладі Північної Ірландії, Шотландії, Канади, Малайзії, США), можемо стверджувати, що діти 3 ООП отримують доступ до різноманітних дидактичних матеріалів у прийнятній, доступній i цікавій форматі. Адаптація зарубіжного досвіду використання ІКТ в інклюзивному навчанні до українського освітнього простору, надасть можливість долати дітям з ООП бар'єри на шляху до навчання, демонструвати освітні досягнення в можливий їм спосіб та бути успішними.

3 урахованням вищеозначеного, під інклюзивною IT освітою слід розуміти систему послуг із застосуванням різноманітних методів, способів та алгоритмів збору, накопичення, обробки, подання й передачі інформації задля забезпечення процесу комунікації з метою здійснення ефективної діяльності учнів з ООП.

Відтак лише суттєві зміни в структурі системи освіти в напрямку впровадження IT в систему інклюзивного навчання сприятимуть сформуванню якісно нового механізму взаємодії педагогічних інституцій задля забезпечення надання якісної освіти та соціалізації кожної дитини з ООП.

\section{Література}

1. Григорович В. Г. Семантичний Веб: інформаційно-комунікаційна складова соціальної адаптації. Вісник Національного університету Львівська політехніка. Інформачійні системи та мережі. 2014. С. 87-95.

2. Статистичний збірник "Соціальний захист населення України". Державна служба статистики України, ДП "Інформаційно-аналітичне агентство", Київ, 2017.

3. Сучасні засоби ІКТ підтримки інклюзивного навчання : навч.посіб. / за заг. ред. Ю. Г. Носенко. Полтава : ПУЕТ, 2018. $261 \mathrm{c}$.

4. Kamarulzaman A. Potential for Providing Augmented Reality Elements in Special Education via Cloud Computing / Kamarulzaman Ab Aziza, Nor Azlina Ab Aziz, Anuar Mohd Yusof, Avijit Paul. Procedia Engineering. Vol. 41. 2012. P. 333-339.

5. Min Wook Ok, Min Kyung Kim, Eun Young Kang, Brian R. Bryant. How to Find Good Apps: An Evaluation Rubric for Instructional Apps for Teaching Students With Learning Disabilities. Intervention in School and Clinic. 2015. №4. pp. $244-252$.

6. Таровик О. I. Хмарні технології у навчально-виховному процесі :метод. посіб. URL: https://goo.gl/fq2PHA(дата звернення: 19.08.2019).

7. Digital Canada 150 URL: https://www.ic.gc.ca/eic/site/028.nsf/vwapj/DC150EN.pdf/\$FILE/DC150EN.pdf (Last accessed: 17.08.2019).

8. Educational Services of America Wins International Innovation Award from Citrix URL: http://www.prnewswire.com/news-releases/educational-services-of-america-wins-

internationalinnovation-award-from-citrix-151024215.html (Last accessed: 15.08.2019). 
9. ICT for inclusion: reaching more students more effectively. URL: http://iite.unesco.org/ pics/publications/ru/files/3214675(Last accessed:20.08.2019).

10. ICTs in Education for People with Special Needs : specialized training course. Moscow : UNESCO Institute for Information Technologies in Education, 2006. 160 p. URL: http://iite.unesco.org/ pics/publications/en/files /3214644.pdf (Last accessed: 15.08.2019).

11. Information and Communication Technologies in Secondary Education : position paper. Moscow : Unesco Institute for Information Technologies in Education, 2004. 24 p. URL: http://iite.unesco.org /pics/publications/en/files/3214616.pd (Last accessed:15.08.2019).

12. Prevalence of Autism Spectrum Disorders, 14 Sites, United States, 2008. URL: http://www.cdc.gov/ $\mathrm{mmwr} / \mathrm{preview} / \mathrm{mmwrhtml} / \mathrm{ss} 6103 \mathrm{a} 1 \mathrm{htm}$ ?s_cid=ss6103a 1_e (Last accessed: 23.08.2019).

13. The force is with Glow as virtual help links up schools. URL: http://www.scotsman.com/ lifestyle/the-force-is-with-glowas-virtual-help-links-up-schools-1-828684 (Last accessed: 23.08.2019).

14. The Individuals with Disabilities Education Act. URL: http://idea.ed.gov/ (Last accessed: 23.08.2019).

15. The new Education Network for Northern Ireland's Schools. URL: http://www.c2kni.org.uk/ news/nENniLeader.html (Last accessed: 22.08.2019).

\section{References}

1. Hryhorovych V. H. Semantychnyi Veb: informatsiino-komunikatsiina skladova sotsialnoi adaptatsii. Visnyk Natsionalnoho universytetu Lvivska politekhnika. Informatsiini systemy ta merezhi. 2014. C. $87-95$.

2. Statystychnyi zbirnyk "Sotsialnyi zakhyst naselennia Ukrainy". Derzhavna sluzhba statystyky Ukrainy, DP "Informatsiino-analitychne ahentstvo", Kyiv, 2017.

3. Suchasni zasoby IKT pidtrymky inkliuzyvnoho navchannia : navch.posib. / za zah. red. Yu. H. Nosenko. Poltava: PUET, 2018. $261 \mathrm{~s}$.

4. Kamarulzaman A. Potential for Providing Augmented Reality Elements in Special Education via Cloud Computing / Kamarulzaman Ab Aziza, Nor Azlina Ab Aziz, Anuar Mohd Yusof, Avijit Paul. Procedia Engineering. Vol. 41. 2012. P. 333-339.

5. Min Wook Ok, Min Kyung Kim, Eun Young Kang, Brian R. Bryant. How to Find Good Apps: An Evaluation Rubric for Instructional Apps for Teaching Students With Learning Disabilities. Intervention in School and Clinic. 2015. №4. pp. 244-252.

6. Tarovyk O. I. Khmarni tekhnolohii u navchalno-vykhovnomu protsesi :metod posib.URL: https://goo.gl/fq2PHA(data zvernennia: 19.08.2019).

7. Digital Canada 150 URL: https://www.ic.gc.ca/eic/site/028.nsf/vwapj/DC150EN.pdf/\$FILE/DC150EN.pdf (Last accessed: 17.08.2019).

8. Educational Services of America Wins International Innovation Award from Citrix URL: http://www.prnewswire.com/news-releases/educational-services-of-america-winsinternationalinnovation-award-from-citrix-151024215.html (Last accessed: 15.08.2019).

9. ICT for inclusion: reaching more students more effectively. URL: http://iite.unesco.org/pics/publications/ru/files/3214675(Last accessed:20.08.2019).

10. ICTs in Education for People with Special Needs : specialized training course. Moscow : UNESCO Institute for Information Technologies in Education, 2006. 160 p. URL: http://iite.unesco.org/pics/publications/en/files /3214644.pdf (Last accessed: 15.08.2019).

11. Information and Communication Technologies in Secondary Education : position paper. Moscow : Unesco Institute for Information Technologies in Education, 2004. 24 p. URL: http://iite.unesco.org /pics/publications/en/files/3214616.pd (Last accessed: 15.08.2019).

12. Prevalence of Autism Spectrum Disorders, 14 Sites, United States, 2008. URL: http://www.cdc.gov/ mmwr/preview/mmwrhtml/ss6103al.htm?s_cid=ss6103a 1_e (Last accessed: 23.08.2019).

13. The force is with Glow as virtual help links up schools. URL: http://www.scotsman.com/ lifestyle/the-force-is-with-glowas-virtual-help-links-up-schools-1-828684 (Last accessed: 23.08.2019).

14. The Individuals with Disabilities Education Act. URL: http://idea.ed.gov/ (Last accessed: 23.08.2019).

15. The new Education Network for Northern Ireland's Schools. URL: http://www.c2kni.org.uk/news/nENniLeader.html (Last accessed: 22.08.2019) 